\title{
A multidisciplinary approach to the study of the fluminense vegetation*
}

\author{
ALPHONSE KELECOM, GEISA L. REIS, PAULO C.A. FEVEREIRO, JANIE G. SILVA, \\ MARCELO G. SANTOS, CÍCERO B. MELLO NETO, MARCELO S. GONZALEZ, \\ RITA C.S. GOUVEA and GILBERTO S.S. ALMEIDA
}

Departamento de Biologia Geral, Universidade Federal Fluminense, Cx. Postal 100.436 24001-970 Niterói, RJ, Brazil

Manuscript received on September 24, 2001; accepted for publication on October 16, 2001; presented by ОтTо R. GotTLIEB

\begin{abstract}
The fluminense vegetation, more specifically the flora from the Jurubatiba restinga has been investigated by a multidisciplinary team of botanists, chemist, radiobiologist, insect physiologists and geneticist. Vouchers of 564 specimens have been collected, identified, organized in an herbarium, and a database is being build up containing, in addition to classical botanical data, chemical data and information on the potential economic use either for landscape gardening, alternative foods or as medicinal plants. Phytochemical studies of the Guttiferae, Clusia hilariana, yielded oleanolic acid and nemorosone. Their biological activities against the haematophagous insect Rhodnius prolixus vector of Chagas disease have been investigated. Finally, it has been observed that aquatic plants possessed high levels of the natural radionuclide polonium-210, which seems to be originated mainly from soil rather than from atmospheric supply.
\end{abstract}

Key words: taxonomy, economic use, oleanolic acid, nemorosone, polonium-210, biological activities.

\section{INTRODUCTION}

The State of Rio de Janeiro (Brazil) is characterized by a great diversity of ecosystems that include rocky coasts, large lagoons, mangroves and restingas (sandbanks) on the seaside, and on the countryside a vast plain extending to the mountain range composed of the Serras dos Órgãos, das Araras and da Mantiqueira, which is connected to a table-land that continues in the neighboring states of São Paulo and Minas Gerais. The vegetal communities are diversified and include i.a. the reminiscent part of the

Correspondence to: Alphonse Kelecom

E-mail: egbakel@vm.uff.br / kelecom@uol.com.br

Fax: 55-21-2719-5934

*Presented by G.L. Reis as an invited talk in XXII RESEM (2000).
Atlantic tropical rain forest and the typical restinga vegetation, object of the present study.

Restingas were formed, along the Brazilian coast, during the Holocene period, as a result of consecutive transgressions and regressions of the sea. They are characterized by large sandy plains of sedimentary origin that are rippled by rows of dunes isolating lagoons, lakes, ponds, bogs and marshes. Such a diversity of physical conditions gives rise to a great diversity of habitats that are colonized by a great variety of vegetal communities. Restingas are thus complex ecosystems in very delicate equilibrium that possess a typical flora, well adapted to the edaphic conditions (Araújo and Lacerda 1987). A number of investigations have appeared dealing mainly with geomorphologic, limnological, botan- 
ical and ecological aspects of Brazilian restingas, most of which situated in the state of Rio de Janeiro (Lacerda et al. 1982, 1984). The restinga of Jurubatiba, however, has been almost overlooked although it possesses a rich and well preserved vegetation including some endemic species and some species in extinction. This restinga is located 250 $\mathrm{km}$ Northeast of Rio de Janeiro City ( $22^{\circ}$ to $22^{\circ} 23^{\prime} \mathrm{S}$ and $41^{\circ} 15^{\prime}$ to $41^{\circ} 45^{\prime} \mathrm{W}$ ), extending from Macaé to Carapebus and Quissamã. The climate of the Jurubatiba area vary from warm and rainy in the summer to dry in the winter, the mean temperature oscillates from 22 to $24^{\circ}$, and the yearly precipitations are comprised between 1,000 and $1,350 \mathrm{~mm}$.

The vegetation of the Jurubatiba restinga and the structure of the vegetal communities have been described only recently (Araújo et al. 1998, 2000). Although little anthropic impact has been observed so far, there is a need for a general study of the Jurubatiba restinga, since the littoral area is being rapidly occupied by holiday houses and the border area, distant from the sea, is being threatened by an extensive sugar cane culture. All its area is now protected by law since April 29, 1998.

The following work is part of a broad multidisciplinary study of the Fluminense vegetation aiming the identification of plants with potential economic use (e.g. for landscape gardening, alternative foods or as medicinal plants) and that can eventually be useful to the local population.

\section{MATERIAL AND METHODS}

Botanical work - Ten collections of botanical material have been organized since May 1995. Until now, 564 plant samples have been collected. Photographic documentation of all plants has been done in situ. Collected material has been herborized following conventional techniques, and identified by us (GLR, PCAF, MGS and JGS). Incomplete botanical material or highly uncommon samples were identified by specialists from the Botanical Garden and from the National Museum of Rio de Janeiro. Ethnobotanical and ethnopharmacological data were obtained from the local population and from an herbalist well acquainted with the vegetation of the Jurubatiba restinga.

A data-base is being build up containing all necessary information, such as voucher number, botanical family, scientific name, local names, synonymies, short description, habitat, name of the collector, date and local of collection, number of replicates, geographic distribution, local uses, and any other pertinent information such as chemical data, literature data on pharmacological uses, etc.

Phytochemical work - Fruits and flowers of the Guttiferae (=Clusiaceae) Clusia hilariana Schlecht were collected every year at the end of September/beginning of October, since 1995 (voucher numbers: 106, 369, 518 and 568). Fruits and flowers were air-dried in the shadow, at room temperature. Ground fruits (199g), male (418g) and female (74g) flowers were separately extracted exhaustively by room temperature percolation with hexane. Filtration and evaporation of the extraction solvent under vacuum furnished a viscous reddish-brown gum (fruits: $29.8 \mathrm{~g}, 15 \%$; male flowers: $49.4 \mathrm{~g}, 12 \%$ and female flowers: $4.3 \mathrm{~g}, 5.8 \%$ ). TLC examination in several solvent systems indicated that the male and female flowers extracts were almost identical except for one compound, hilarione A, much less abundant or even absent in the female flowers and whose structure will be reported elsewhere. The fruits extract was more complex and contained, in addition to the metabolites reported here, a series of triterpenes that were not investigated. Each extract was purified in the same way. A type purification is as follows.

The crude hexane extract $(24 \mathrm{~g})$ was partitioned between hexane and aqueous methanol (10\% water). The upper phase contained untreated material and the lower phase contained oleanolic acid (1) and nemorosone (2) together with other polar compounds (TLC). After evaporation of the solvents, the lower layer was evaporated to dryness and the residue submitted to a second partition between hexane and aqueous methanol (25\% water). Evaporation of the solvents yielded impure nemorosone (2) in the upper layer and oleanolic acid (1) in the lower 
one (TLC). Silica gel filtration of impure nemorosone (eluent: hexane EtOAc 10\%) afforded pure compound $2(620 \mathrm{mg})$ as a pale yellowish gum $\left(\mathrm{R}_{\mathrm{f}}=0.53\right.$, silica gel plate eluted with hexane-EtOAc 4:1). The oleanolic acid was purified by crystallization from methanol and identified as its methyl ester (3) from ${ }^{1} \mathrm{H}$ and ${ }^{13} \mathrm{C}-\mathrm{NMR}$ data and by direct comparison with an authentic sample. Nemorosone was identified as its acetyl-derivative (4), by comparison of spectral data with published data on nemorosone methyl ether (5) (Oliveira et al. 1996). We here report unpublished data on the nemorosones $\mathrm{A}$ and B (2a+2b): IR $v_{\max } \mathrm{cm}^{-1}$ (film on $\left.\mathrm{NaCl}\right)$ : 35503150, 1718, 1700, 1650, 1580; ${ }^{1} \mathrm{H}-\mathrm{NMR}(300 \mathrm{MHz}$, $\left.\mathrm{CDCl}_{3}\right) \delta_{\mathrm{H}}$ from TMS: $\mathrm{H}-9,13(7.64+7.48, d 7.8)$, $\mathrm{H}-10,12$ (7.23, 7 , 8), H-11 (7.39, t7,8), $\mathrm{H}_{2}-14$ (2.40 to 2.70 , complex $), \mathrm{H}-15(\sim 5.10, m), \mathrm{H}_{3}-17(1.70$ $+1.74, s / s), \mathrm{H}_{3}-18(1.66+1.67, s / s), \mathrm{H}_{2}-19(3.10$ to 3.30 , complex), $\mathrm{H}-20(5.10, m), \mathrm{H}_{3}-22(1.66+$ $1.70, s / s), \mathrm{H}_{3}-23(1.62+1.67, s / s), \mathrm{H}_{2}-24$ (2.05 to 2.70, complex), $\mathrm{H}-25$ (not observed), $\mathrm{H}_{3}-27$ (1.17 $+1.13, s / s), \mathrm{H}_{3}-28(1.35+1.40, s / s), \mathrm{H}_{2}-29(2.06$ to 2.20 , complex), $\mathrm{H}-30(4.98, m), \mathrm{H}_{3}-32(1.66+$ $1.70, s / s)$ and $\mathrm{H}_{3}-33(1.56+1.58, s / s) ;{ }^{13} \mathrm{C} \mathrm{NMR}(75$ $\left.\mathrm{MHz}, \mathrm{CDCl}_{3}\right) \delta_{\mathrm{C}}$ from TMS: C-1 $(64.81+57.33)$, C-2 $(207.32+206.59)$, C-3 $(71.96+78.63)$, C$4(194.64+170.20)$, C-5 $(119.40+118.24)$, C6 (167.19 + 191.92), C-7 (193.02), C-8 (137.67 + 136.74), C-9,13 (128.14), C-10,12 (127.59), C$11(131.94+131.76), \mathrm{C}-14(29.50+29.20), \mathrm{C}-$ $15(119.48+119.96), \mathrm{C}-16(136.96+136.27), \mathrm{C}-$ 17,22,32 (25.79, 25.67, 25.58), C-18,23,33 (17.94, 17.74, 17.69), C-19 (23.86 + 22.49), C-20 (118.09 $+118.24), \mathrm{C}-21(134.08+135.59), \mathrm{C}-24(42.28+$ 39.82), C-25 (42.57+43.15), C-26 (47.18+48.24), C-27 (24.22 + 23.25), C-28 (13.93 + 15.70), C$29(27.47+26.72), \mathrm{C}-30(122.30+122.35)$ and $\mathrm{C}-$ 31 (133.07); ${ }^{1} \mathrm{H}-{ }^{1} \mathrm{H}$ COSY cross-peaks $(\mathrm{H \#} \rightarrow \mathrm{H} \#)$ : $14 \mathrm{a} \rightarrow 14 \mathrm{~b}, 15,18 ; 14 \mathrm{~b} \rightarrow 14 \mathrm{a}, 15,18 ; 15 \rightarrow 14 \mathrm{a}, 14 \mathrm{~b}$, $18 ; 18 \rightarrow 14 a, 14 b, 15,27 ; 19 a \rightarrow 19 b, 20,23 ; 19 b \rightarrow$ $19 \mathrm{a}, 20,23 ; 20 \rightarrow 19 \mathrm{a}, 19 \mathrm{~b}, 22,23 ; 22 \rightarrow 20 ; 23 \rightarrow 19 \mathrm{a}$, $19 \mathrm{~b}, 20 ; 24 \mathrm{a} \rightarrow 24 \mathrm{~b} ; 24 \mathrm{~b} \rightarrow 24 \mathrm{a}, 25 ; 25 \rightarrow 24 \mathrm{~b}, 29 \mathrm{~b}$; $29 \mathrm{a} \rightarrow 29 \mathrm{~b}, 30 ; 29 \mathrm{~b} \rightarrow 25,29 \mathrm{a}, 30 ; 30 \rightarrow 29 \mathrm{a}, 29 \mathrm{~b}, 32$ and $32 \rightarrow 30$.
Biological activities - Fourth-instar larvae of Rhodnius prolixus were used. Following ecdysis, larvae were starved for 25-30 days and then fed on citrated human blood, using a membrane apparatus described previously (Garcia and Rembold 1984). Oral treatment was performed by adding, to the blood meal of the larvae, samples dissolved in ethanol-saline 1:4 at concentrations from 1 to $100 \mu \mathrm{g} / \mathrm{ml}$. Groups of 35 insects were allowed to feed, as above. Insects were weighted immediately before and after feeding to determine the amount of ingested blood. Only fully gorged insects were used. Partially fed ones were discarded. Controls received blood with solvent only. Insects were maintained at $28^{\circ} \mathrm{C}$ during the experiments. The biological activities were observed and recorded for toxicity (i.e. $24 \mathrm{~h}$ mortality), molting retardation and molting stasis. The data were registered every week after treatment, the periods of observation being of 4-5 weeks. This period accommodated the maximum molting periods of the control groups. Significance of the results was calculated using the $\chi^{2}$-test.

Radioecological work - Six plants were collected from the "Blau-Blau" marsh (Carapebus, RJ) and identified as: Chara sp (Chlorophyceae), Ceratopteris thalictroides (L.) Brongn. (Parkeriaceae), Hedyotis thessifolia St.-Hil. (Rubiaceae), Nymphaea ampla (Salisbury) DC. (Nymphaeaceae), Nymphoides humboldtianum (H.B.K.) O. Kunt (Menyanthaceae) and an unidentified species of Cyperaceae. Several specimens of each plant were deposited at the Herbarium under the numbers 148 and 364 (C. thalictroides), 71 and 157 (H. thessifolia), 398 and 497 (N. ampla) and 69, 155 and 511 (N. humboldtianum). Leaves, stems, roots and associated soils were separated, partially air-dried in shadowed area and then carried to the laboratory in plastic bags.

All the samples were dried at constant weight at $80-100^{\circ} \mathrm{C}$, ground in a mortar, weighted $(1.0-2.0 \mathrm{~g}$ dry mass) and mineralized at $100^{\circ} \mathrm{C}$ with a mixture of concentrated $\mathrm{HNO}_{3}$ and $\mathrm{HClO}_{4}(12: 1 \mathrm{ml} / \mathrm{g})$, for $10-15 \mathrm{~h}$. The wet mineral residues were treated 
with $\mathrm{HCl} 12 \mathrm{~N}$ (1-2ml), to produce chlorides and then allowed to dry. Spontaneous electrodeposition of ${ }^{210} \mathrm{Po}$ on stainless steel discs was carried out, in the usual way (Gouvea et al. 1987), by treatment of the mineral residue with $100 \mathrm{ml} \mathrm{HCl}$ $0.5 \mathrm{~N}$ and $250 \mathrm{mg} \mathrm{L}$-ascorbic acid at $80^{\circ} \mathrm{C}$, under continuous stirring for $2.5 \mathrm{~h}$. The disks were then washed with distilled water, dried and counted by total alpha scintillometry using a $\mathrm{ZnS}(\mathrm{Ag})$ crystal (Halden and Harley 1960) coupled to a photomultiplier and a pulse counter. Calculations of the ${ }^{210} \mathrm{Po}$ concentrations (in $\mathrm{mBq} \cdot \mathrm{g}^{-1}$ ) took into consideration radiochemical yields (98\%), radiometric efficiency $(31.4 \%)$ and the equivalent of conversion d.p.h./mBq.

\section{RESULTS AND DISCUSSION}

The flora of the Jurubatiba restinga is constituted by several vegetal communities: restinga forest, marsh forest, Clusia habitats, Ericaceae habitats, Palmae habitats, periodically inundated areas, permanently inundated areas, lakes and beach environments, inter alii (Araújo et al. 1998). Plants distribution in these communities has been the object of recent studies, and 618 vascular species have been identified. They belong to 381 genera and 120 families (Araújo et al. 2000). Among these species, several are used not only as foods or as medicinal plants, but also for a number of other applications that will be briefly commented.

\section{BOTANICAL, ETHNOBOTANICAL}

\section{AND ETHNOPHARMACOLOGICAL RESUlts}

Ten collections of botanical material have been organized in the Jurubatiba restinga between May 1995 and April 2000. Collected plants were herborized, identified taxonomically and an herbarium is being organized. Some species are endemic and some are almost extinguished, for example Couepia schottii Fritshi, Jacquinia brasiliensis Mez, Molinedia glabra (Sprengel) Perkins and Pavonia alnifolia St. Hill. Production of plantlets and cuttings is underway, aiming preservation and propagation of these species.
So far, 564 specimens have been collected. One hundred and eighteen species belonging to 98 genera and 48 families have been identified as "useful species", either because they are effectively used by local population or because they are potentially useful species. The complete list of all these species is beyond the scope of this paper and will be published elsewhere (Reis et al. 2001). The most economically important families are: Myrtaceae (with 10 species), Clusiaceae (6) and Rubiaceae (6), but the Leguminosae (5), Asteraceae (5) and Bromeliaceae (5) are also of great interest. Considering the number of species reported for these families in the Jurubatiba restinga (Araújo et al. 2000), it can be deduced that $47 \%$ of the Myrtaceae found in Jurubatiba are used or useful, $26 \%$ of the Bromeliaceae, $21 \%$ of the Rubiaceae, $16 \%$ of the Asteraceae, but only $11 \%$ of the Leguminosae.

A database is being built up containing, in addition to classical botanical data, chemical data and informations on the potential economic uses. Thus, among the 118 useful species: $26 \%$ are medicinal plants, $23 \%$ are edible (some being very appreciated), $20 \%$ are timber-trees, $16 \%$ are ornamental and can be used for landscape gardening, 5\% furnish fibers used to make ropes and whips, and that have potential use in the textile industry, $3 \%$ are ingredients for religious practices and $7 \%$ have miscellaneous uses (flavors, aromatics, pigments, etc.).

The edible species belong to three major families: Myrtaceae (9 species), Arecaceae (4) and Cactaceae (3), the principal species being identified as: Anacardium occidentale L. (cajueiro), Astrocaryum ayri M. (airi), Cereus pernambucensis (cacto-branco), Eugenia uniflora L. (local name: pitangueira), Genipa americana L. (genipapeiro), $\mathrm{Hu}$ miria balsamifera (Aubl.) St. Hill. (pau-preto), Passiflora alata Ait. (maracujá-açú), P. alliacea Barb. Rodr. (sururuca), P. mucronata Lam. (maracujá-mirim), Protium heptaphyllum March (almesca fêmea), Psidium cattleyanum Sab. (araçazeiro), Rapanea parviflora Mez. (capororoca), Tapirira guianensis Aubl. (crioulo) and Tipha dominguensis Person. (taboa). Their fruits may be eaten as such or 
may be used to prepare jams or juices.

Ethnobotanical and ethnopharmacological information was furnished by local population and by Jorge Inácio Barcelos, an herbalist habitant of the Jurubatiba restinga where he was born. The medicinal plants belong to 17 families, with Myrtaceae and Asteraceae (4 species each), and Rubiaceae and Verbenaceae ( 3 species each) as the most important ones. Plants are mainly used as anti-diarrheic (10 species), to heal wounds (4), against fever (4), as anesthetic (3) and also for a number of other minor uses. For a more complete information about these popular uses, one should refer to the work of Reis and coworkers (Reis et al. 2001). One should note that the diarrhea problem is a typical problem of tropical countries, where poor population usually uses bad quality water to drink and to cook their food.

\section{Phytochemical Results}

Besides the studies of Kaplan and co-workers on leaf waxes, tannins and cyanogenic glycosides, litthe is known about secondary metabolites from the restinga vegetation in Brazil (e.g. Kaplan et al. 1983, 1979-2000 and references). Almost nothing has been experimentally established on the biological activities associated to plants from Brazilian restingas, although, as discussed above, several species are used in popular medicine. This is, however, not the case of the Guttiferae (Clusiaceae) a very abundant family in the Jurubatiba restinga, whose principal genus, Clusia, is found associated to one of the most characteristic habitats (Araújo et al. 1998).

Clusia plants are in their majority dioecious and present photosynthetic plasticity, being able to follow the $\mathrm{C}_{3}$ or CAM (Crassulacean Acid Metabolism) pathways (Grams et al. 1998). Literature data inform that Clusia species possess antimicrobial, antiinflammatory, spasmolytic, cytotoxic and antihypertensive activities (Delle Monache et al. 1987, Tomás-Barberán et al. 1993). They are also used in Central and South America to heal headaches, wounds, bone fractures and even leprosy (Usher
1984, Salama 1986, Mathur et al. 1974). Phytochemical studies have yielded $\beta$-sitosterol (Nagem et al. 1993), a number of sesquiterpenes (Gonzalez et al. 1993), some common triterpenes such as $\beta$-amyrine, oleanolic acid, friedeline, epifriedeline, epifriedelinol, lupeol, betulinic acid, euphol and 3keto-euphone (Araújo et al. 1966, Mathur 1972, Salama 1986), the cytotoxic and antimicrobial dihydrophenanthrene paralycolin-A (Delle Monache et al. 1987), the flavonoids (-)-epicatechine, 2''rhamnosyl - vitexone, 6" - acetyl-2" - rhamnosyl vitexine, procyanidine B2 and trimethyl-catechinic acid (Martínez et al. 1996, Barrios et al. 1991) and the cis and trans-tocotrienolic acids, together with a series of intriguing polyprenylated benzophenones (Dreyer 1974, Gonzalez et al. 1983, Delle Monache et al. 1991a, 1991b, Delle Monache et al. 1988, Cerrini et al. 1993, Martínez et al. 1994, González and Martínez 1994, Gonzalez et al. 1995, Henry et al. 1995, 1996, 1999, Oliveira et al. 1996, 1999), a chemical group derived from mixed biosynthesis and that is confined to the Guttiferae (Henry et al. 1999). This section describes the isolation of oleanolic acid (1) and nemorosone in both tautomeric forms (2a and $\mathbf{2 b}$ ).

The hexane extracts of the fruits, male and female flowers of Clusia hilariana were submitted to solvent partition followed by several column chromatographies. This procedure led to the isolation of an unidentified mixture of sesquiterpenes, of one triterpene, oleanolic acid, and of the benzophenone nemorosone.

Oleanolic acid (1) was isolated in large amounts from fruits and in smaller quantities from the resin of both male and female flowers. It was identified as its methyl ester derivative (3) by direct comparison of its ${ }^{1} \mathrm{H}$ and ${ }^{13} \mathrm{C}$ NMR spectral data with those of an authentic sample. This triterpene had already been described from Clusia rosea (whole plant) (Mathur 1972). As far as we are aware, this is the first report of the presence of this triterpene in the floral resin of a Clusia species. Oleanolic acid possesses a number of interesting biological activities that have been reviewed recently (Liu 1995). Remarkably, when 
tested in vitro against HIV-1 reverse transcriptase, oleanolic acid showed moderate activity, inhibiting the enzyme in $15 \%$ (Pereira et al. 1998).

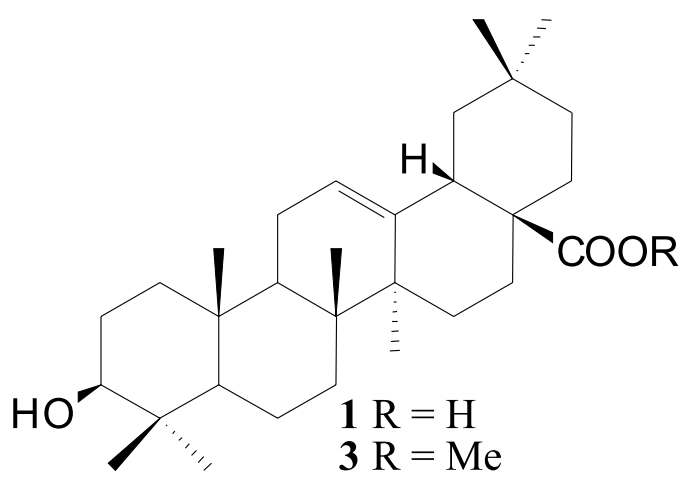

Fig. 1 - Structure of oleanolic acid (1) and of its methyl ester derivative (3).

Nemorosone was isolated as a tautomeric mixture in relative amount 2:3. In what follows, we will refer to these tautomers as nemorosones A (2a) and B (2b) respectively. Nemorosones are the major benzophenones in the resins of both male and female flowers. They are also present in the hexane extract from the fruits. The structure of nemorosones came from comparison of their ${ }^{1} \mathrm{H}$ and ${ }^{13} \mathrm{C}-\mathrm{NMR}$ spectra with data on nemorosone A methyl ether (5) (Oliveira et al. 1996). Nemorosone A (2a) has already been isolated, as the methyl ether $\mathbf{5}$, from several species of Clusia (Oliveira et al. 1996, 1999), but the NMR data of the natural underived metabolite 2a remained unpublished, and its tautomer (2b) had never been described before. Interestingly, methylation $\left(\mathrm{CH}_{2} \mathrm{~N}_{2}, \mathrm{Et}_{2} \mathrm{O}\right.$, r.t. $)$ of nemorosones afforded only methyl ether derivative $\mathbf{5}$. On the contrary, acetylation $\left(\mathrm{Ac}_{2} \mathrm{O}\right.$ and Pyridine, $65^{\circ} \mathrm{C}$, $4 \mathrm{~h}$ ) of the tautomeric mixture yielded exclusively the monoacetate corresponding to the other tautomer (4). Nemorosone, as the mixture of tautomers, showed moderate activity against HIV-1 reverse transcriptase, inhibiting the enzyme in $30 \%$ at a concentration of $100 \mu \mathrm{M}$. Its acetylated derivative (4) was less active (Pereira et al. 1998).

\section{Biological Activities of Clusia Crude} Extracts, AND OF Compounds (1) AND (2)

Besides the ethnopharmacological activities cited above, the other plants are being submitted to a systematic screening, in order to detect toxicity, phagorepellent or anti-ecdysis properties against insect vectors of tropical diseases.

Thus, the hexane, methylene chloride and $\mathrm{MeOH}$ crude extracts of male flowers of $C$. hilariana have been assayed against the haematophagous insect, Rhodnius prolixus, one of the vectors of Chagas disease, at the concentrations of 1,10 and $100 \mu \mathrm{g} / \mathrm{ml}$ blood. No feeding inhibition could be observed, except with the $\mathrm{MeOH}$ extract at the higher dose, that reduced the feeding of the insects in $98.7 \%$. Similarly, the crude extracts did not induce delay of the ecdysis, except for the insects partially fed with blood containing $100 \mu \mathrm{g} / \mathrm{ml}$ of the $\mathrm{MeOH}$ extract.

A preliminary study of the biological activities, on $R$. prolixus, of oleanolic acid and of the mixture of nemorosone $\mathrm{A}$ and $\mathrm{B}$ has also been carried out. Figures 3 and 4 show the toxicity and the antiecdysis effect of oleanolic acid (1) fed at 1, 10 and $100 \mu \mathrm{g} / \mathrm{ml}$ blood. Dose-dependent toxicity and potent anti-molting effect were observed for oleanolic acid. These unexpected activities are now the object of further studies. Figures 5 and 6 show the activities of nemorosones A and B (2a+2b) fed at 1 and $10 \mu \mathrm{g} / \mathrm{ml}$ blood. It appears that the nemorosones are almost non toxic to $R$. prolixus, but a dose-dependent anti-molting activity could be observed that needs further investigation.

\section{Radioecological StUdies}

Several habitats of the Jurubatiba restinga are constantly or seasonally under water. The existence of lagoons, lakes, ponds and marches stimulated us to carry out a radioecological study on aquatic plants in order to estimate their capacity to bioaccumulate polonium-210 $\left({ }^{210} \mathrm{Po}\right)$, one of the most important contributors to the active deposit of interest in natural radioactive contamination of the environment (Santos et al. 1970), and that most contributes to 


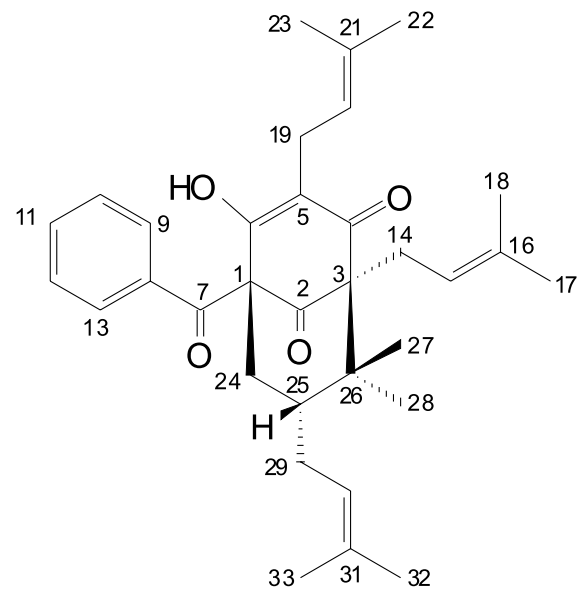

$2 a$

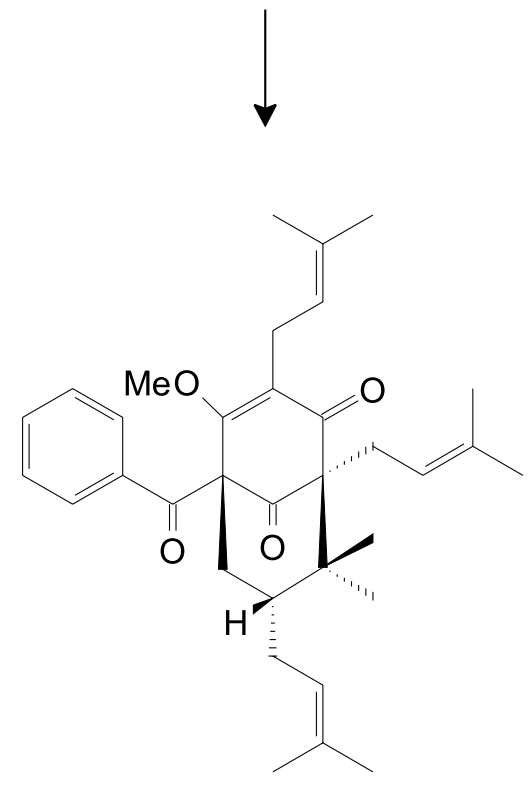

5

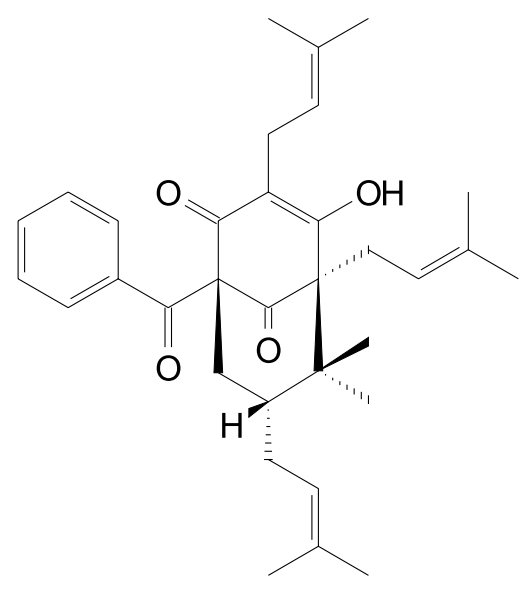

$2 b$

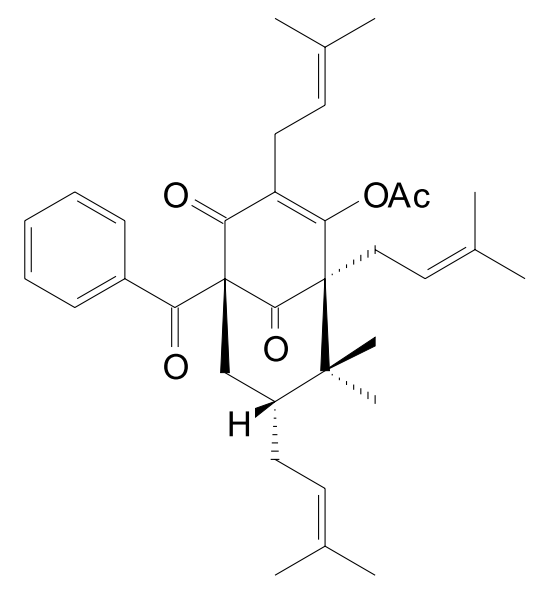

4

Fig. 2 - Structures of nemorosone A (2a) and its methyl ether (5) derivative, and of nemorosone B (2b) and its monoacetate derivative (4).

the internal radiation dose to man (Parfenov 1974).

The occurrence of ${ }^{210} \mathrm{Po}$ in the terrestrial and marine fauna and flora has been studied for almost three decades (Parfenov 1974, Folson and Beasley 1972). It is known that terrestrial plants are able to accumulate ${ }^{210} \mathrm{Po}$ from the soil by their roots, but translocation of this radionuclide to the other parts of the vegetal is usually insignificant (Tso and Fisenne 1968). Indeed, the major contamination of plants occurs through deposition onto the leaves, particularly the hairy ones, by dry rather than by wet deposition. On the contrary, in the marine environment ${ }^{210} \mathrm{Po}$ is directly accumulated from water or from particulate material and is frequently concentrated along food chains (Stegnar and Kobal 1982). Little attention, however, has been paid to freshwater plants and vegetation from Brazilian restingas had never been examined (Lacerda et al. 1982, INIS 


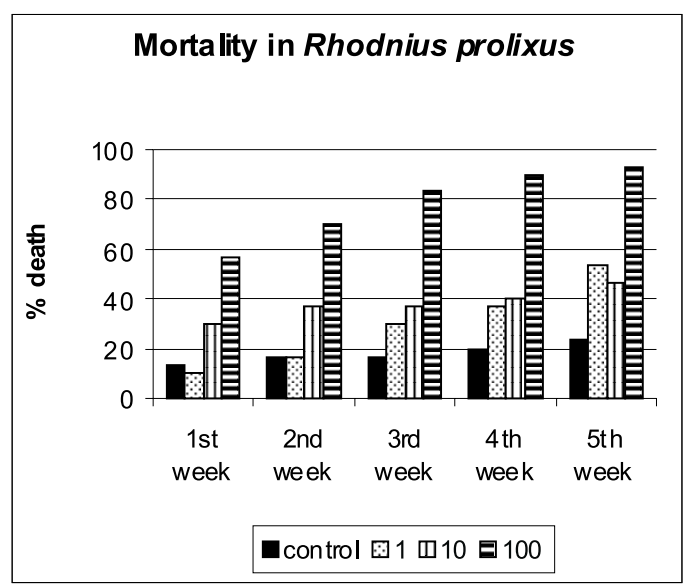

Fig. 3 - Toxicity of oleanolic acid (1). Concentrations in $\mu \mathrm{g} / \mathrm{ml}$.

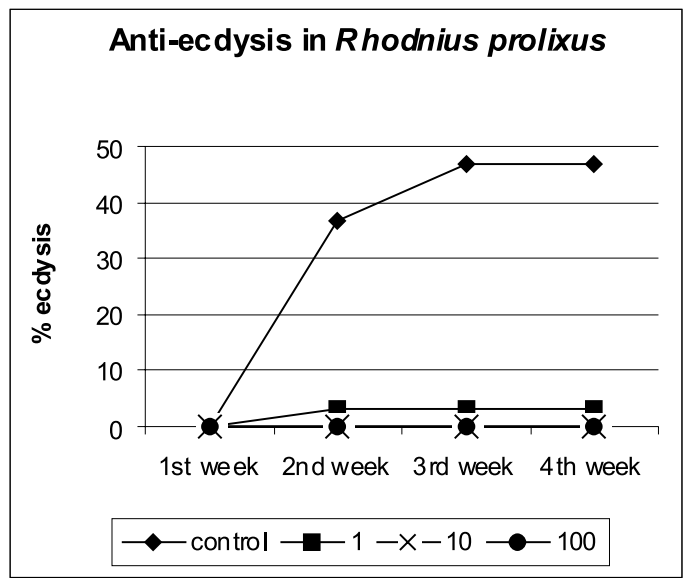

Fig. 4 - Anti-molting activity of (1). Concentrations in $\mu \mathrm{g} / \mathrm{ml}$.

data base 1948-1998).

Six plants, one green alga and five aquatic plants, have been collected from the "Blau-Blau" marsh, and analyzed for their ${ }^{210} \mathrm{Po}$ content. The results that have been published recently (Kelecom et al. 1999) are reproduced and complemented in Table I. The alga showed elevated concentrations of ${ }^{210} \mathrm{Po}$, similar to those observed for marine algae. All the other plants showed the lowest concentration of ${ }^{210} \mathrm{Po}$ in the stems and the highest in the roots. Intermediate values were observed in the leaves. The unexpected high concentrations of ${ }^{210} \mathrm{Po}$ in the roots must be due to the elevated level of this radionuclide

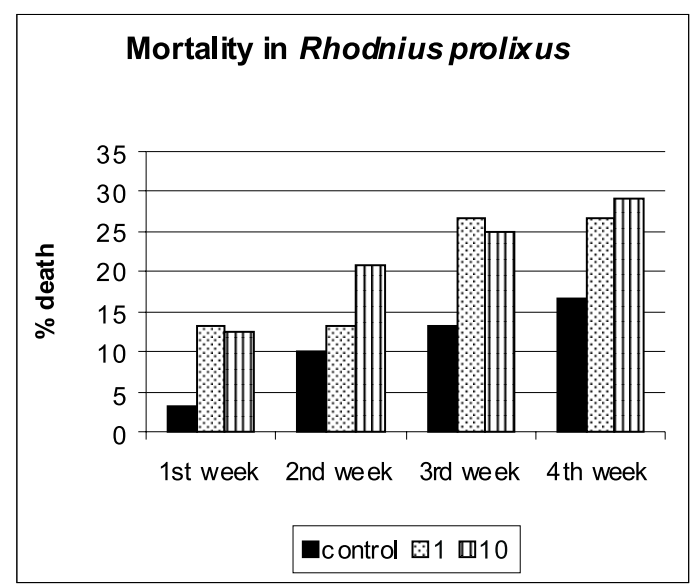

Fig. 5 - Toxicity of nemorosones A and B $(\mathbf{2} \mathbf{a}+\mathbf{2} \mathbf{b})$. Concentrations in $\mu \mathrm{g} / \mathrm{ml}$.

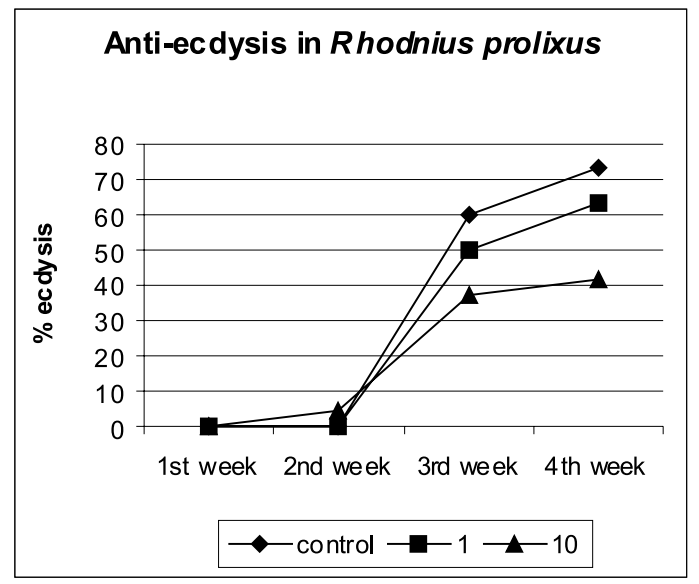

Fig. 6-Anti-molting activity of nemorosones A and B (2a+2b). Concentrations in $\mu \mathrm{g} / \mathrm{ml}$.

in associated soils. For a deeper discussion about the significance of these results, see Kelecom et al. (1999).

\section{CONCLUSIONS}

The multidisciplinary study described here resulted in the obtainment of a rich collection of plants from the Jurubatiba restinga. An herbarium and an associated database are being built up. This has furnished leads for the rational choice of plants for phytochemical research. Hence, the abundant Gut- 
TABLE I

Radioactive concentration (in $\mathrm{mBq} / \mathrm{g}$ ) of polonium-210 in freshwater aquatic plants of the “Blau-Blau', pond, Restinga of Jurubatiba (Carapebus, RJ, Brazil).

\begin{tabular}{l|c|c|c|c}
\hline plant & leaf & stem & root & soil \\
\hline Ceratopteris thalictroides & $95.4 \pm 11.5$ & n.d. & $116.4 \pm 10.5$ & $121.4 \pm 15.7$ \\
\hline Chara sp (green alga) & \multicolumn{4}{|c}{ whole plant: $129.9 \pm 23.4$} \\
\hline Cyperacea & culm \& leaf: $20.3 \pm 5.1$ & $124.8 \pm 19.9$ & $158.6 \pm 17.5$ \\
\hline Hedyotis thessifolia & $41.4 \pm 11.6$ & $16.3 \pm 4.4$ & $41.2 \pm 13.7$ & $60.0 \pm 16.2$ \\
\hline Nymphea ampla & $30.7 \pm 9.5$ & $19.1 \pm 5.4$ & $58.1 \pm 19.7$ & $123.5 \pm 18.5$ \\
\hline Nymphoides humboldtianum & $25.0 \pm 7.8$ & $29.7 \pm 10.1$ & $71.2 \pm 16.4$ & $161.2 \pm 29.0$ \\
\hline
\end{tabular}

n.d. = not determined

tiferae, C. hilariana has been investigated. So far, two secondary metabolites have been isolated and identified: the triterpene oleanolic acid and the benzophenone nemorosone (in tautomeric equilibrium). These substances showed interesting physiological effects on the insect $R$. prolixus. On the other hand, radioecological studies of six aquatic plants showed unexpected high capacity to concentrate polonium210. We are now planning to extend our work to the study of the interactions between insects and plants. Thus, the almost extinguished butterfly, Parides ascanius Cramer 1775, specific of the marshy restingas of the State of Rio de Janeiro, maintains a specific relationship with the plant Aristolochia macroura, since the butterfly larvae only develop on cited plant. $P$. ascanius is a brightly colored butterfly (aposematic colors) that seems to possess a chemical protection from dietary origin. The study of this insectplant interaction is now under way in our laboratories.

\section{ACKNOWLEDGMENTS}

AK, CBMN and MSG thank the Scientific Research Council (CNPq) for research fellowships. We are indebted to our university for travel facilities to Carapebus. We are grateful to Prof. M. Cecília B.V. de Souza (Department of Organic Chemistry, UFF) for recording the NMR spectra of nemorosones. A number of students were trained in laboratory tech- niques and research methodologies. The following students participated of parts of this study: A.A. Ribeiro, Alba Valéria dos Santos, Ana Maria Martins Lucas, Artur Maciel, Elaine Coelho Majdalani, F.D. Martins, José Mauro Lima da Silva, Marco Antonio Rocha, P.G. Vargas and Vanuse Rangel Tavares. Their help is acknowledged. Finally, we are grateful to Jorge Inácio Barcelos for the invaluable information he furnished and for his constant help during the collecting trips.

\section{RESUMO}

A vegetação fluminense, em particular aquela proveniente da Restinga de Jurubatiba, foi investigada por um grupo multidisciplinar de botânicos, químico, radiobiólogo, fisiologistas de insetos e geneticista. Amostras de 564 espécimes foram coletadas, identificadas, organizadas em herbário e um banco de dados está sendo elaborado contendo, além das clássicas informações botânicas, dados químicos e indicações quanto ao uso econômico potencial destas plantas, em paisagismo, como alimentos alternativos ou como plantas medicinais. Estudos fitoquímicos da Guttiferae, Clusia hilariana, forneceram ácido oleanólico e nemorosona. Estes metabólitos foram ensaiados no barbeiro Rhodnius prolixus, vetor da doença de Chagas. Por fim, observou-se que plantas aquáticas apresentaram teores muito altos do radionuclídeo natural, polônio-210, fato este que parece estar relacionado mais com as condições de solo do que com um aporte atmosférico. 
Palavras-chave: taxonomia, uso econômico, ácido oleanólico, nemorosona, polonium-210, atividades biológicas.

\section{REFERENCES}

AraúJo DSD AND LACERDA LD DE. 1987. A natureza das restingas. Ciência Hoje 6: 42-48.

Araújo DSD, Scarano FR, Sá CFC, Kurtz BC, ZALuAR HLT, Montezuma RCM AND Oliveira RC. 1998. Comunidades vegetais do Parque Nacional da Restinga de Jurubatiba. In: ECOlOGIA DAS LagOAS costeiras do Parque Nacional da Restinga de Jurubatiba e do Município de MacaÉ, Rio DE JANEIRO. Universidade Federal do Rio de Janeiro, Rio de Janeiro, pp. 39-62.

Araújo DSD, Costa AF, Oliveira AS and Moura RL. 2000. Flora do Parque Nacional da Restinga de Jurubatiba e arredores, Rio de Janeiro: listagem, florística e fitogeografia; Angiosperma - Pteridófitas - Algas continentais, Rio de Janeiro, Museu Nacional do Rio de Janeiro (Série Livros 8).

Araújo HC de, Mahajan JR, Gottlieb OR AND Magalhães MT. 1966. A química de Gutíferas Brasileiras. $\mathrm{X}$ - Constituintes triterpênicos de uma Clusia. An Acad Bras Cienc 38: 429-430.

Barrios M, Calvo M, Arguedas E and Castro O. 1991. Epicatequina en Clusia stenophylla y Clusia flava. Ing Cienc Quim 13: 27-28.

Cerrini S, Lamba D, Delle Monache F and Pinheiro RM. 1993. Nemorosonol, a derivative of tricyclo-[4.3.1.0 $\left.0^{3,7}\right]$-decane-7-hydroxy-2,9-dione from Clusia nemorosa. Phytochemistry 32: 10231028.

Delle Monache F, Delle Monache G, Cavalcanti JF AND PINHEIRo RM. 1987. An unexpected dihydrophenanthrene from Clusia paralycola. Tetrahedron Lett 28: 563-566.

Delle Monache F, Delle Monache G, PinheiRO RM AND RADICS L. 1988. Nemorosonol, a derivative of tricyclo[4.3.1.0 $\left.0^{3,7}\right]$-decane-7-hydroxy2,9-dione from Clusia nemorosa. Phytochemistry 27: 2305-2308.

Delle Monache F, Delle Monache G and GácsBAITZ E. 1991a. Two polyiso-prenylated ketones from Clusia nemorosa. Phytochemistry 30: 703-705.
Delle Monache F, Delle Monache G and GácsBAItz E. 1991b. Prenylated benzophenones from Clusia sandinensis. Phytochemistry 30: 2003-2005.

Dreyer DL. 1974. Xanthochymol from Clusia rosea (Guttiferae). Phytochemistry 13: 2883-2884.

Folson TR AND BEASLEY TM. 1972. Contributions from the alpha emitter, polonium-210, to the natural radiation environment of the marine organisms, p. 2-10. In IAEA Symposium on the interaction of radioactive contaminants with the constituents of the marine environment, 324p.

Garcia ES AND Rembold H. 1984. Effects of azadirachtin on ecdysis of Rhodnius prolixus. J Insect Physiol 30: 939-941.

GonzÁlez GJ and Martínez OE. 1994. Clusiacitran B, una benzofenona obtenida de hojas de Clusia ellipticifolia. Rev Colomb Quim 23: 37-41.

Gonzalez J, Cuellar U, Bettancourt A and Pinzon MI. 1983. A benzophenone from the fruits of Clusia ellipticifolia. Phytochemistry 22: 2088-2090.

Gonzalez J, Martinez E, Moreno B and Delle Monache F. 1993. Hidrocarburos sesquiterpénicos presentes en espécies del género Clusia. Rev Colomb Quim 22: 81-84.

Gonzalez JG, Olivares EM and Delle Monache F. 1995. Citrans and cyclols from Clusia multiflora. Phytochemistry 38: 485-489.

Gouvea RCS, Santos PL and Gouvea VA. 1987. Contribution to the study of radioactivity in marine organisms; dosage of ${ }^{210} \mathrm{Po}$ in Perna perna, L. Sci Total Environ 61: 117-120.

Grams TeE, Herzog B and Luettge U. 1998. Are there species in the genus Clusia with obligate $\mathrm{C}_{3}$ photosynthesis? J Plant Physiol 152: 1-9.

HALDEN NA AND HARLEY SH. 1960. An improved alphacounting technique. Anal Chem 32: 1861-1863.

Henry Ge, Jacobs H, Mclean S, Reynolds WF AND YANG J-P. 1995. Xerophenones A and B. New isoprenylated derivatives of 11-oxatricyclo $\left[4.3 \cdot 1.0^{4,10}\right]$ undecane-7,9-dione from Clusia portlandiana (Guttiferae). Tetrahedron Lett 36: 4575-4578.

Henry GE, Jacobs H, Sean Carrington CM, McLean S AND ReYNOLDS WF. 1996. Plukenetione A. An unusual adamantyl ketone from Clusia plukenetii (Gut- 
tiferae). Tetrahedron Lett 39: 8663-8666.

Henry GE, Jacobs H, Sean Carrington CM, McLean S AND Reynolds WF. 1999. Prenylated benzophenone derivatives from Caribbean $\mathrm{Clu}$ sia species (Guttiferae). Plukenetiones B-G and xerophenone A. Tetrahedron 55: 1581-1596.

INIS data-base, Nuclear Information Service (CIN) of the Brazilian National Commission for Atomic Energy (CNEN), covered period 1948-1998.

Kaplan MaC, Figueiredo and Gottlieb OR. 1983. Variation in cyanogenesis in plants with season and insect pressure. Biochem Syst Ecol 11: 367-370.

Kaplan MAC et AL. 1979-2000. Abstracts. Proceed of the Ann Meeting on Micromolecular Evol Syst and Ecol - RESEM I-XXII.

Kelecom A, Santos PL, Gouvea RC, Dutra IR and Fevereiro PCA. 1999. Teores elevados de Polônio210 em plantas aquáticas da restinga de Carapebus, Carapebus-RJ. Química Nova 22: 666-668.

LaCerda LD de, AraúJo DSD de AND Maciel NC. 1982. Restingas Brasileiras: uma bibliografia, Universidade Federal do Rio de Janeiro (Brazil), 55 p. 471 references.

Lacerda LD de, Araújo DSD de, Cerqueira R AND TurCQ B. 1984. Restingas: Origem, Estrutura, Processos. Universidade Federal Fluminense Printing Office - CEUFF, Niterói RJ, Brazil, 477 p.

LIU J. 1995. Pharmacology of oleanolic acid and ursolic acid. J Ethnopharmacol 49: 57-68.

Martínez OE, Gonzalez GJ and Delle Monache F. 1994. Benzophenones from Clusia ellipticifolia. Phytochemistry 36: 473-475.

Martínez OE, Moreno-Murillo B and Delle Monache F. 1996. Fukugetina y fukogisida, bisflavonoides de Clusia guaviarensis Cuatr. (Clusiaceae). Rev Colomb Quim 25: 15-21.

Mathur SB. 1972. Triterpenoid constituents of Clusia rosea. Phytochemistry 11: 1513-1514.

Mathur SB, Chaves S and Firmin X. 1974. VI Int Congr Essential Oils, 30, 6 pp. Cited in Salama AM. 1986. Aislamiento de friedelina y friedelinol de la corteza de Clusia ellipticifolia Cuatr.). Rev Colomb Quim Farmacéutica: 99-104.
Nagem TJ, da Silva MC, Mesquita AAL and Silva R. 1993. Constituents of Clusia arboricida. Fitoterapia 64: 87.

Oliveira CMA de, Porto AM, Bittrich V, Vencato I AND MARsAioli AJ. 1996. Floral resins of Clusia spp.: chemical composition and biological function. Tetrahedron Lett 37: 6427-6430.

Oliveira CMA de, Porto AM, Bittrich V And MarSAIOLI AJ. 1999. Two poly-isoprenylated benzophenones from the floral resins of three Clusia species. Phytochemistry 50: 1073-1079.

PARFENOV YD. 1974. Polonium-210 in the environment and in the human organism. Atomic

Pereira HS, Kelecom A, Oliveira AF, Maciel A, FerRaZ NV, Moussatché N and Frugulhetti ICPP. 1998. Evaluation of the effect of benzophenones on HIV-1 reverse transcriptase. Virus: Rev and Res 3 (Supl. 1): 84.

Reis GL, Fevereiro PCA, Santos MG and Barcelos JI. 2001. Plantas com potencial econômico do Parque Nacional da Restinga de Jurubatiba, Rio de Janeiro, Brasil, Acta Botanica Brasilica.

Salama AM. 1986. Friedelin and friedelinol from Clusia ellipticifolia. Rev Latinoam Quim 16: 117-118.

Santos PL, Weinberg EM, Franca EP. 1970. Determinação de ${ }^{210}$ Po em cigarros e tabaco. Rev Biol y Med Nuclear 2: 73-77.

Stegnar P and Kobal I. 1982. Uptake and distribution of radium and uranium in the aquatic food chain, p. 364-373. In: International Atomic Energy Agency; Commission of the European CommuNities ANd Nuclear ENERgy Agency, 1982, Enviromental migration of long-lived radionuclides.

Tomás-Barberán FA, Garcia-Viguera C, Olivier PVT, Ferreres F And Tomás-Lorente F. 1993. Phytochemical evidence for the botanical origin of tropical propolis from Venezuela. Phytochemistry 34: 191-196.

Tso TC And Fisenne I. 1968. Translocation and distribution of lead-210 and polonium-210 supplied to tobacco plants. Rad Bot 8: 451-462.

Usher G. 1984. Dictionary of Plants, CBS, Delhi, INDIA, pp. 113-114, 161, 266-268, 502, 562 and 602. 